\title{
The Taste Bud and Its Innervation in the Rat as Studied by Immunohistochemistry for PGP 9.5
}

\author{
Hiroaki KanaZawa ${ }^{1}$ and Sumio Yoshie ${ }^{2}$ \\ Department of Anatomy ${ }^{1}$, Niigata University School of Medicine; and Department of Histology ${ }^{2}$, Nippon Dental University \\ School of Dentistry at Niigata, Niigata, Japan \\ Received June 8, 1996
}

\begin{abstract}
Summary. The taste bud in the rat vallate papillae was observed by immunohistochemistry for PGP 9.5 at the light and electron microscope levels; routine transmission electron microscopy was also performed. Immunoreactivity for PGP 9.5, a marker protein of paraneurons, was localized in the cytoplasm of the Type III or gustatory cells. More intensive immunoreactivity occurred in the nerve fibers, though a part of the nerve fibers remained unstained.

The nerve fibers as detected by the immunostaining and by routine electron microscopy formed a coarse subepithelial plexus which issued branches upwards through the basal lamina. In the basal portion of the taste bud, these fibers formed a hitherto unknown intragemmal plexus of dense and delicate meshwork. This plexus, in turn, extended beaded fibers between the taste bud cells, forming synaptic contacts with Type III cells. Some of the immunoreactive nerve fibers were confirmed to reach the taste pore by light microscopy; electron-microscopic examination could not demonstrate their directly being exposed to the space of the taste pore.

This study also deals with the fine structure of the rat taste bud with special reference to the Type III cells and their synapses with nerve fibers, as the rat has recently been rather seldom used in this field of study.
\end{abstract}

The structure of taste buds in vertebrates has been investigated by light microscopists since the last century (SCHWALBE, 1867; RETZIUS, 1892; KolmER, 1927). While modern light microscope studies could differentiate light and dark cells forming the taste bud (Murray, 1969; MurRAY and MURRAY, 1967, 1971), electron microscope observations disclosed the occurrence of cells with various electron opacities and finestructural features (for reviews, see KINNAMON and Cummings, 1992; ReUTTER and WitT, 1993). Some authors conceived that different cell types might represent the stages of differentiation of a single cell line (ENGSTRÖM and RYTZNER, 1956; GRAZIADEI, 1969; DELAY et al., 1986).

Electron microscope studies on the taste buds of rabbit foliate papillae performed by MURRAY (1969, 1971) and his associates (MURRAY et al., 1969; MURRAY and MurRAY, 1967, 1971; FujIMOTO and MurRAY, 1970) differentiated three cell types, Types I, II and III cells, which these authors suggested to have differentiated from an immature progenitor, the basal cell. Recent studies by the research group of KINNAMON in the same species confirmed and extended the results gathered by MURRAY's group (ROYER and KINNAMON, 1991, 1994).

Meanwhile, TAKEDA (1976) and her associates (TAKEDA and KITAO, 1981; TAKEDA et al., 1981) used the mouse taste bud, mainly in vallate papillae, in their electron microscope observations and contributed toward clarifying the synaptic nature of Type II and III cells.

Recently the research group of YOSHIE investigated the fine structure of the taste buds in the guinea pig (YosHIE et al., 1990, 1991b) and a variety of other animals including the dog (KANAZAWA, 1993), cat, rat and rabbit (YosHIE, unpublished) in combination with the immunohistochemical analysis of neuron-specific proteins. Comparing the data obtained from these animals led them to determine that the conclusion concerning the cell types and functions of the taste bud reached by the previous authors-mainly in the rabbit and partly in the mouse-was valid as a unified rule for mammals, which namely is as follows:

The Type I cell, appearing dark in its cytoplasm both under the light and electron microscopes and lacking a nervous connection, is the supportive element of the taste bud. The Type II cell, clear in its cytoplasm, receives a synapse-like contact of nerve terminals. An unknown sensory function has been ascribed to this cell, which lacks synaptic vesicles but is provided with a subsurface cistern. The Type III 
cell, intermediate in cytoplasmic opacity, is the gustatory cell as its ample synapses show fine structures typical of chemical transmission. In this cell type, YoshiE et al. (1991a, 1994) succeeded, in demonstrating in guinea pigs, the exocytotic opening of synaptic vesicles/granules by stimulating the taste bud apices with different taste substances. The Type IV cell is the basal cell representing a progenitor to be differentiated into the above three cell types.

It is worthy to note that the rat, one of the most popular laboratory animals, has been used in only a few, early electron microscope studies of the taste bud. FARBMAN (1965) observing this species, distinguished between dark and light cells and proposed to designate them Type I and II cells, respectively-the terminolgy which came to be adopted by later investigators. UGA (1969) demonstrated typical structures of synapses in his light cells. TAKEDA and HosHiNO (1975) left a more detailed description of the taste bud cells in vallate and foliate papillae of the rat, dividing them into Types I, II and III. As more recent papers dealing with the fine structure of rat taste buds are not available as far as is known, our knowledge concerning this subject in the rat remains meager as compared with certain other mammals including the rabbit, mouse and guinea pig.

Supporting the view that the gustatory cell represents one of the typical sensory paraneurons (FUJITA, 1976), recent immunohistochemical studies by YoSHIE and associates $(1988,1989,1991 \mathrm{~b})$ have indicated the occurrence in the Type III or gustatory cell of neuronspecific proteins, which are known to be shared by certain endocrine and sensory paraneurons (reviews: FujiTA et al., 1988; IwANAGA et al., 1989). This type of taste bud cell in the guinea pig has been demonstrated to contain neuron-specific enolase (NSE) (YOSHIE et al., 1988) and spot 35 or Purkinje cell-specific protein (IwANAGA et al., 1985; Yoshie et al., 1988). Immunoreactivity for PGP (protein gene product) 9.5, another marker of neurons also known to be shared by certain types of paraneurons, has been preliminar- ily detected in the taste buds of the rat (IwANAGA et al., 1992).

Concerning the innervation of the taste bud, early studies using silver impregnation and methylene blue staining revealed that the subgemmal plexus comprising numerous unmyelinated nerves sends fibers into the taste bud (for review, see KOLMER, 1927); some of these intragemmal fibers were depicted as ascending up to the taste pore (ARNSTEIN, 1893; BOTEZAT, 1902; RetziUs, 1912; MÜller, 1996). Nishimoto et al. (1982) demonstrated substance P-immunoreactive fibers terminating close to the taste pore. Electron microscope studies revealed that nerves form a typical synapse with the Type III cell and a synapse-like association of unknown function with the Type II cell (MurRay and MurRay, 1967, 1971). Studies on the innervation of murine taste buds have also been meager since the work by PARAN et al. (1975), who demonstrated in the rat the subgemmal plexus and its branches into the bud by electron-microscopic histochemistry of acetylcholine esterase.

The present study aims to make the morphological information of rat taste buds more precise than previously by means of immunohistochemistry for PGP 9.5 at the light and electron-microscopic levels. Special reference is given to the gustatory cells which are selectively immunoreactive, and the distribution and morpholgy of the subgemmal and intragemmal nerve fibers which are distinctly immunostained for PGP 9.5.

\section{MATERIALS AND METHODS}

\section{Light-microscopic immunohistochemistry}

Male Wistar rats, weighing $180-250 \mathrm{~g}$, were used in this study. The animals were anesthetized with pentobarbital and perfused with a physiological saline followed by $4 \%$ paraformaldehyde solution (in $0.1 \mathrm{M}$ phosphate buffer, $\mathrm{pH}$ 7.4). The tongue was removed

Fig. 1. Immunohistochemistry of PGP 9.5 in a rat circumvallate papilla. Bundles of immunoreactive nerve fibers form a coarse subepithelial network (SEN). Condensations of immunoreactive fibers in the basal portion of taste buds represent intragemmal plexuses (arrowheads) which extend fibers into the taste bud. Some of the taste bud cells are immunoreactive. $\times 300$

Fig. 2. Closer view of a taste bud immunostained for PGP 9.5. A few spindle shaped cells and nerve fibers are immunoreactive. The intragemmal nerve plexus is condensed in a narrow basal portion of the taste bud (arrows). The immunoreactive bud cells and nerve fibers are closely associated. These immunoreactive nerve fibers exhibit knob-like swellings (arrowheads). $\times 930$

Fig. 3. Taste buds and their nerve supply shown by immunohistochemistry for PGP 9.5. The immunoreactive nerve fibers form the intragemmal plexus above the basement membrane (arrows). An immunoreactive fiber is shown to enter the perigemmal region of the epithelium (asterisk). The arrowheads indicate the attachment of an immunoreactive cell and immunoreactive nerve fibers. $\times 800$ 

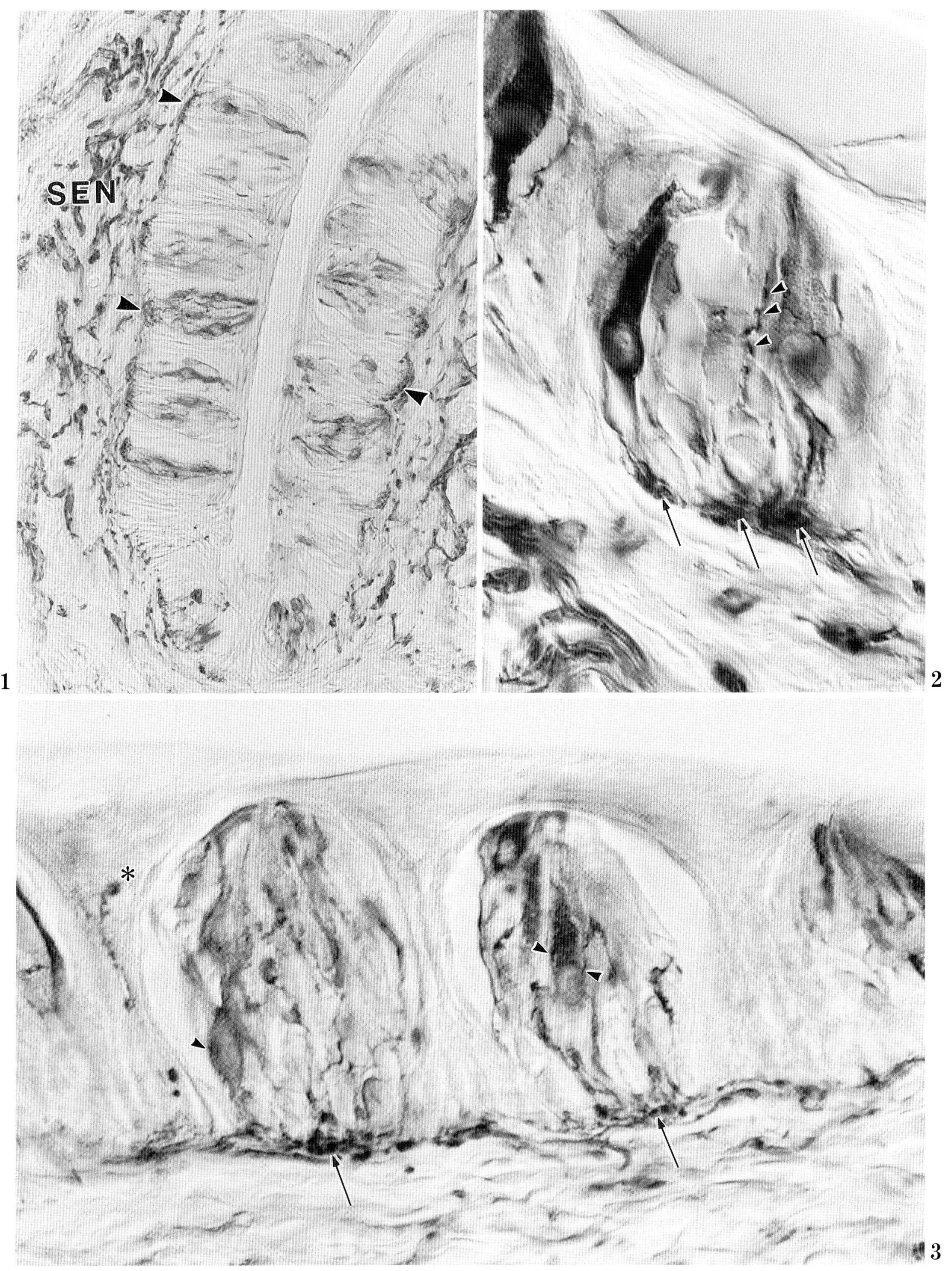

Figs. 1-3. Legends on the opposite page. 

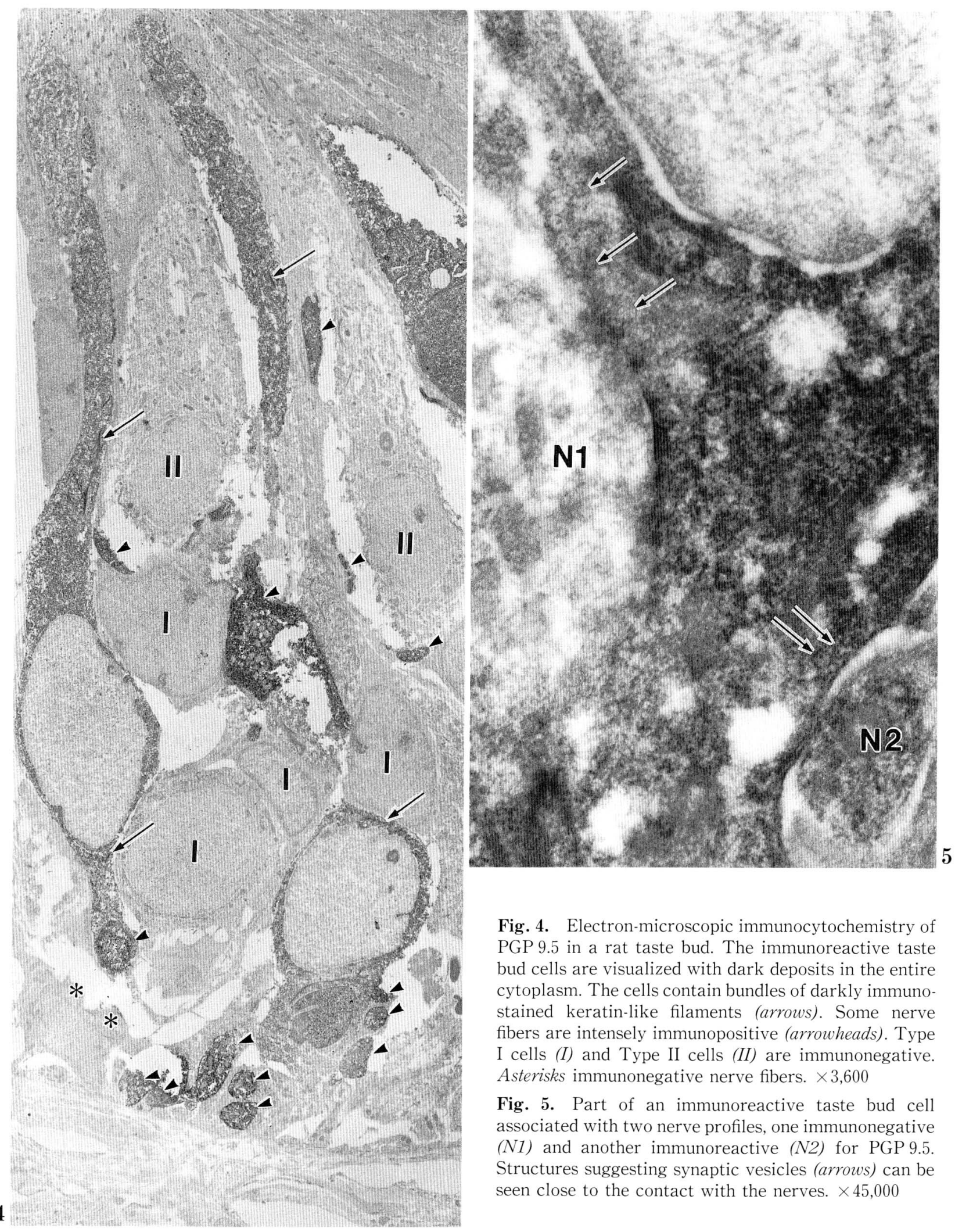

Fig. 4. Electron-microscopic immunocytochemistry of PGP 9.5 in a rat taste bud. The immunoreactive taste bud cells are visualized with dark deposits in the entire cytoplasm. The cells contain bundles of darkly immunostained keratin-like filaments (arrows). Some nerve fibers are intensely immunopositive (arrowheads). Type I cells (I) and Type II cells (II) are immunonegative. Asterisks immunonegative nerve fibers. $\times 3,600$

Fig. 5. Part of an immunoreactive taste bud cell associated with two nerve profiles, one immunonegative (N1) and another immunoreactive (N2) for PGP 9.5. Structures suggesting synaptic vesicles (arrows) can be seen close to the contact with the nerves. $\times 45,000$ 
and immersed in the same fixative for an additional $6 \mathrm{~h}$. Tissue pieces containing the vallate papillae were immersed in a $30 \%$ sucrose solution and rapidly frozen in liquid nitrogen. Frozen sections were prepared in a cryostat (Coldtome CM 41, Sakura) and processed for the avidin-biotin complex (ABC) method. The antiserum used in this study was a rabbit anti-PGP 9.5 serum purchased from Ultraclone (Cambridge, U.K.). The sections were incubated overnight with the antiserum diluted to $1: 3,000$. The antigenantibody reaction was visualized by a Streptoavidinbiotin staining kit (Nichirei, Histofine SAB-PO, Tokyo).

\section{Electron-microscopic immunohistochemistry}

Some of the cryostat sections immunostained by the $\mathrm{ABC}$ method were fixed with $1 \% \mathrm{OsO}_{4}$ for $30 \mathrm{~min}$, dehydrated in an ethanol series and embedded in Araldite resin. Ultrathin sections were prepared and stained with lead citrate before examination in a Hitachi H-7000 electron microscope.

\section{Conventional electron microscopy}

The animals were anesthetized with pentobarbital and perfused with a physiological saline followed by $2.5 \%$ glutaraldehyde solution (in $0.1 \mathrm{M}$ phosphate buffer, $\mathrm{pH}$ 7.4). The tongue was removed and immersed in the same fixative for an additional $6 \mathrm{~h}$. After being rinsed in the buffer, the specimens were post-fixed in $2 \% \mathrm{OsO}_{4}$ in the buffer for $2 \mathrm{~h}$, dehydrated through a graded ethanol series and propylene oxide, and embedded in Epon resin. Ultrathin sections were cut on a Reichert Ultracut- $\mathrm{N}$ ultramicrotome with a diamond knife, double stained with uranyl acetate and lead citrate, and examined in a Hitachi H-7000 electron microscope.

\section{OBSERVATIONS}

\section{Immunohistochemistry for PGP 9.5}

Immunohistochemical procedures using anti-PGP 9.5 antibody revealed clearly stained cells representing a minor population (approximately 10\%) of the cells composing the taste bud. More intense immunoreactivity was demonstrated in nerve fibers under the epithelium and in the taste bud (Fig. 1).

The immunoreactive cells in the taste bud were slender spindle-like forms with an oval nucleus that was located mostly at the middle level but occasionally more or less shifted to the apex or to the base (Fig. 2). The cells spanned the apical end of the taste bud with its base facing the basement membrane.
The immunoreactivity was represented by a homogeneous substance filling the entire cytoplasm, whereas the nucleus remained unstained. The immunoreactive cells tended to be located in peripheral portions of the bud (Fig. 2). They were mostly separated from each other, being intercalated by unstained cells, though occasionally juxtaposed with other stained cells.

The PGP 9.5-immunoreactive nerve fibers were demonstrated to form a horizontally extended network of fiber bundles occupying a subepithelial layer ranging from the basement membrane to a level about 50 $\mu \mathrm{m}$ below it (Fig. 1). The immunoreactive fibers were numerous, but apparently comprised a part of the nerves forming the subgemmal plexus.

From the subgemmal plexus many immunoreactive fibers, separated into single fibers, were sent to the taste bud (Figs. 1, 3). They passed the basement membrane to form a dense and delicate plexus just above the basement membrane (Figs. 2, 3). This intragemmal plexus, which was condensed in a narrow basal portion (5-8 $\mu \mathrm{m}$ in thickness) of the taste bud, issued fine immunoreactive branches upward between the cellular elements of the bud; these often revealed knob-like and varicose swellings, and mostly were in close contact with the immunoreactive spindle-like cells (Fig. 2). An immunoreactive cell appeared to be attached by the nerves at two, three, or more sites (Fig. 3). This nervous contact occurred at different levels of the cell-not only in its basal half but also in its apical portion. Some of the immunoreactive fibers coursed between unstained cells, but their contact with them was difficult to determine (Fig. 3). Some nerve fibers ascended to reach the taste pore, but it was difficult to determine that their ends might be exposed to the taste pore (Figs. 1, 3).

A part of the immunoreactive nerve fibers invaded the perigemmal region of the epithelium to some depth (Fig. 3). A detailed description of these fibers is not included in this paper.

\section{Electron-microscopic immunohistochemistry}

The PGP 9.5-immunoreactive elements were examined by electron microscopy using the pre-embedding method. The immunoreactive spindle-like cells were clearly visualized by dark deposits dispersed in the entire cytoplasm (Fig. 4). It was evidenced more clearly than in light micrographs that the slender cytoplasm extended from the taste pore to the base of the bud. Granular structures including ribosomes, keratin-like bundles (vide infra) and other filamentous materials, and cytoplasmic condensations at the synaptic contact (vide infra) appeared dark (Fig. 5); 


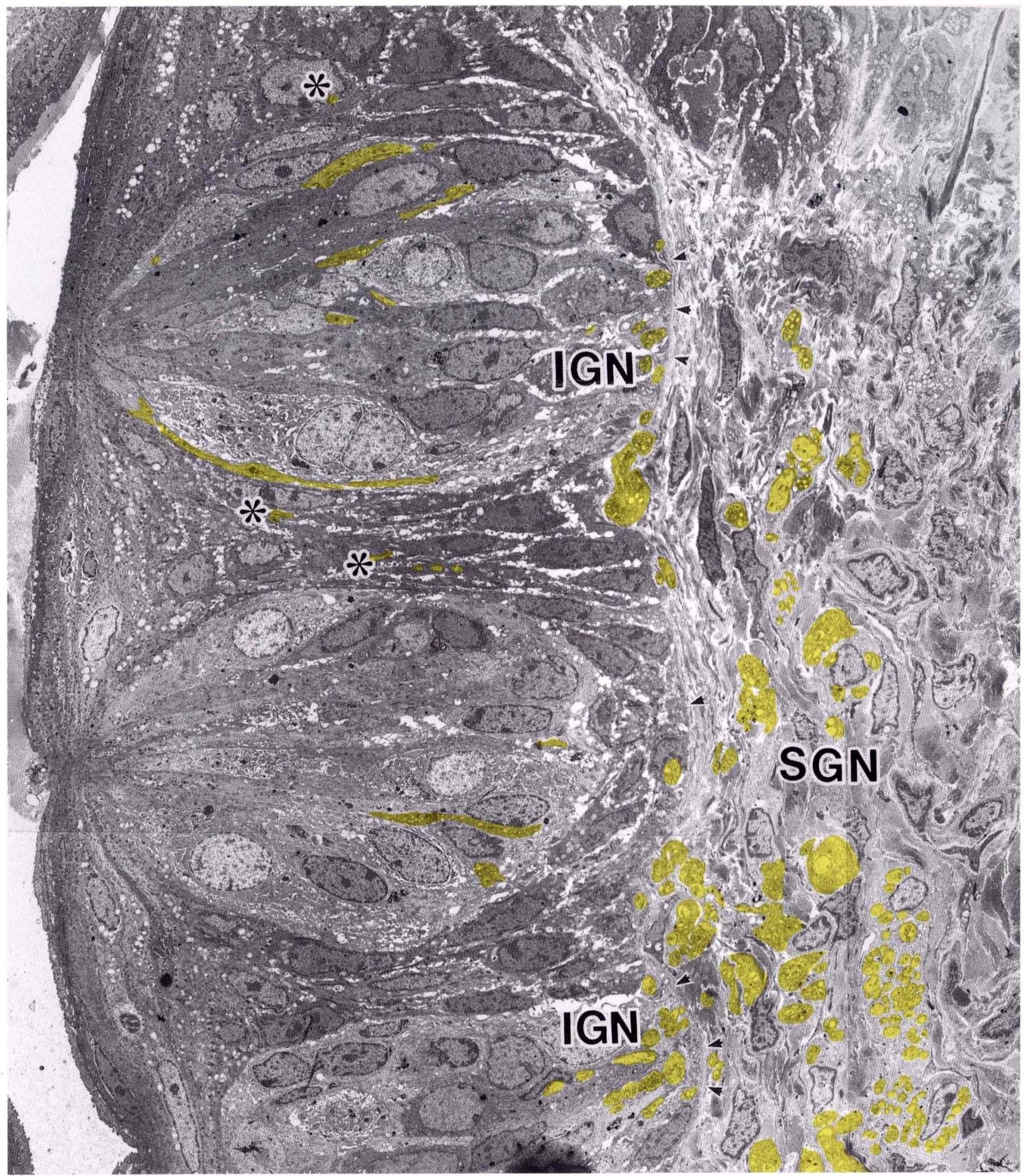

Fig. 6. Low magnification of a rat circumvallate papilla by conventional transmission electron microscopy. Bundles of nerve fibers colored yellow are seen to form a subgemmal nerve plexus (SGN). Condensations of fine nerve fibers above the basal lamina (arrowheads) correspond to the intragemmal nerve plexuses (IGN). Some nerve fibers extend to the apical portion of the taste buds. Some of the immunoreactive nerve fibers enter the perigemmal region of the epithelium (asterisks). $\times 1,400$ 


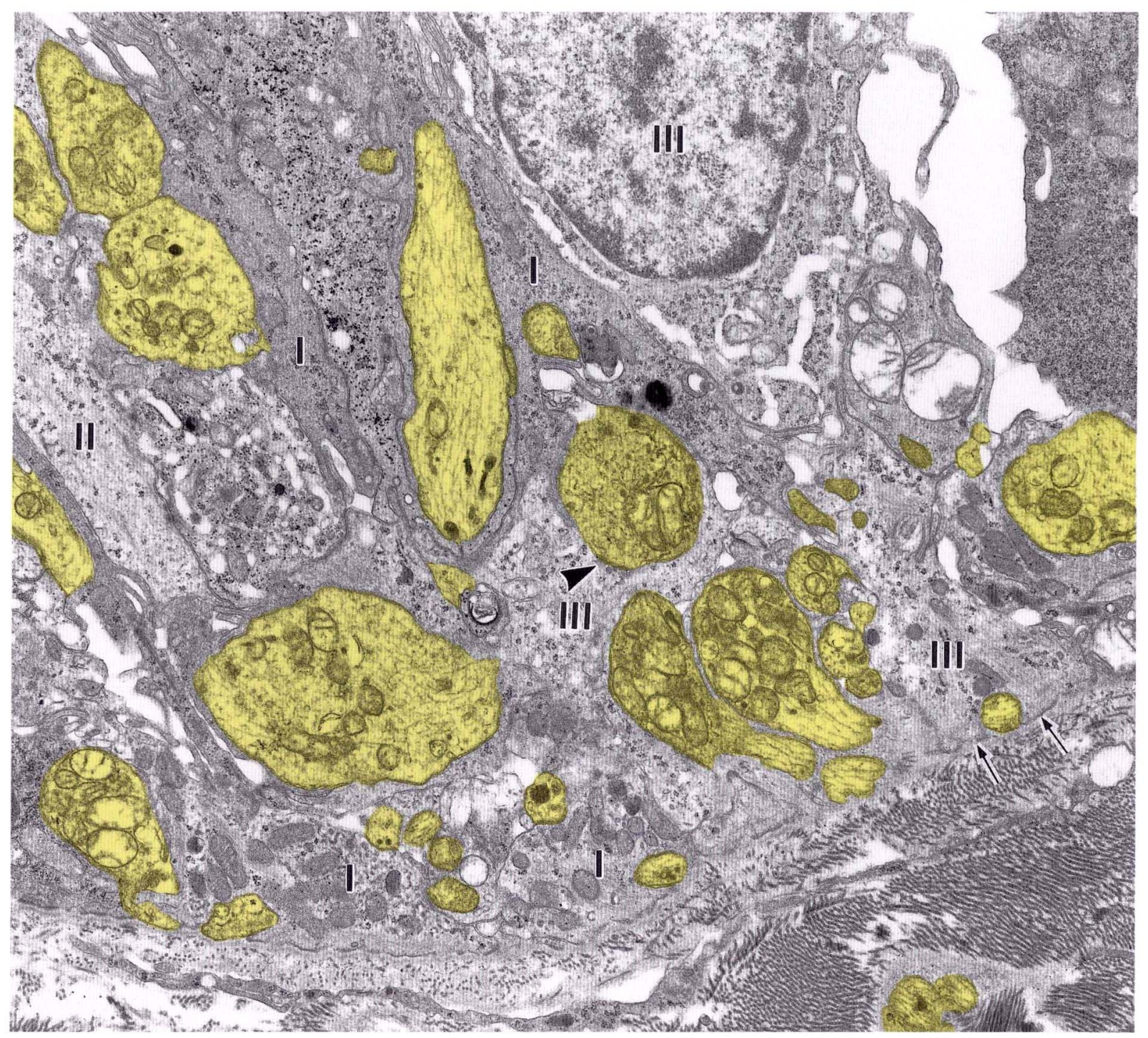

Fig. 7. Closer view of a basal portion of a rat taste bud. Numerous profiles of nerve fibers (yellow colored) are seen in the taste bud. A Type III cell extends down to the basal lamina (arrows). The arrowhead indicates a synapse. I Type I cell, II Type II cell, III Type III cell. $\times 12,000$

mitochondria tended to remain unstaind.

The structure of the nucleus and the distribution of cytoplasmic elements indicated that the immunoreactive cells corresponded to the Type III or gustatory cells, though the elements tended to be damaged due to the immunoreaction (Fig. 5). To support this cell identification, we were able to demonstrate synaptic contacts of the immunostained cells with nerve terminal varicosities, though synaptic vesicles and granules were partly destroyed or obscured by the immunoreaction. The immunostained cells were observed to contain bundles of darkly immunostained keratinlike filaments, which were confirmed to occur in the
Type III cells in routine electron micrographs (vide infra).

PGP 9.5 immunostaining demonstrated numerous profiles of nerve fibers forming the dense intragemmal plexus extending above the basement membrane as observed by light microscopy (Fig. 4). Some profiles of nerve fibers were immunonegative, it being most likely that the PGP 9.5 antibody demonstrated the majority of, but not all elements of the intragemmal nerves (Fig. 4). The nerve terminals associated with the immunostained Type III cells were mostly immunoreactive for PGP 9.5, though a part of them remained unreactive (Fig. 5). The immunoreactive 


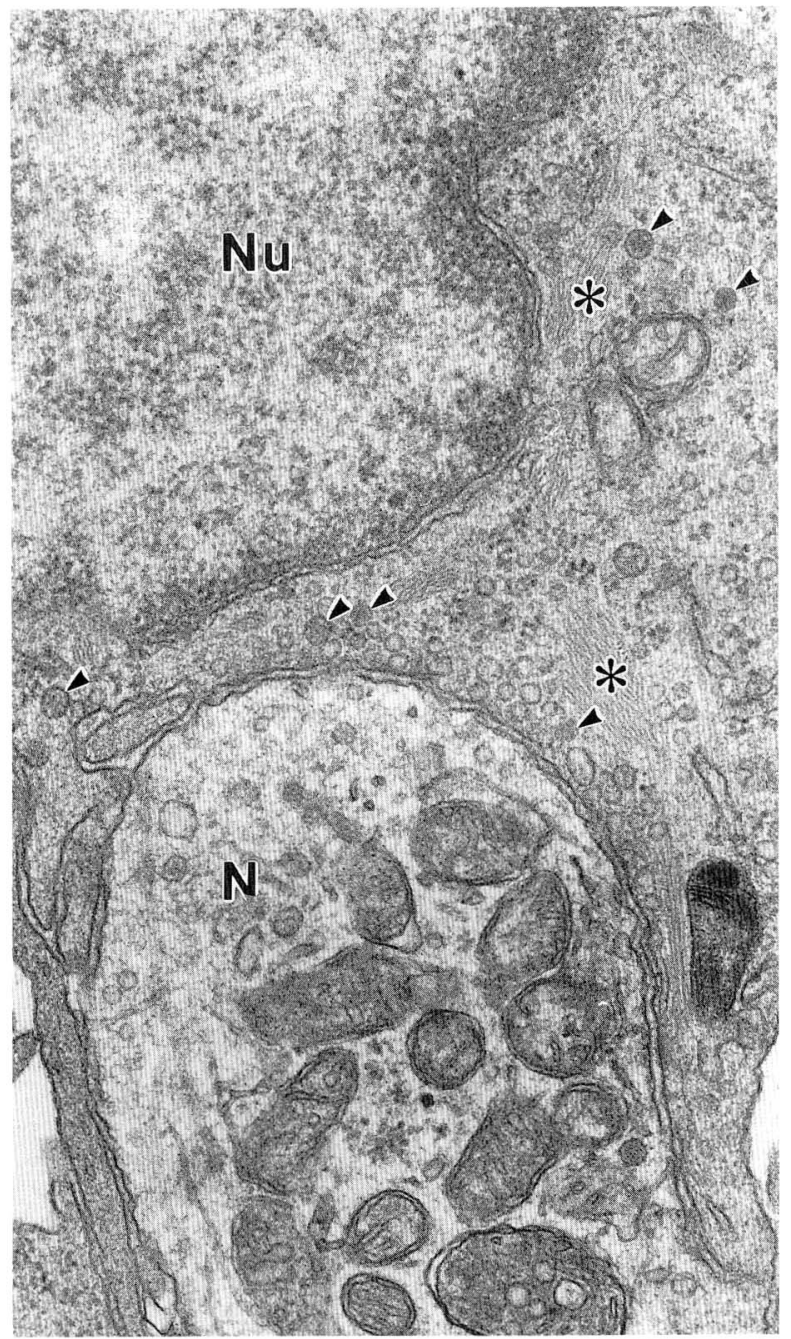

Fig. 8. High magnification of a synapse between a Type III cell and a nerve. Numerous small clear vesicles and a few large cored vesicles (arrowheads) are gathered near the synapse. The nerve $(N)$ contains small clear vesicles and large cored vesicles. Asterisks indicate keratin-like filaments. $N u$ nucleus of the Type III cell. $\times 39,000$

and non-reactive nerves were frequently embraced by the cytoplasm of a Type I cell, as if the latter were a glial cell.

\section{Fine structure of the taste bud and its innervation}

The findings from routinely prepared, non-immunostained sections are recorded here for the purpose of supplementing the immunohistochemical observations described above.

The taste bud contained numerous profiles of nerve fibers. They were rcognized at different levels up to the close vicinity of the taste pore (Fig. 6). A conspicuous concentration of the nerve fibers was demonstrated in the lowest zone of the taste bud, corresponding to the intragemmal plexus described above (Fig. 7). Profiles of perigemmal nerves, i.e., fibers distributed in the epithelium close to but outside of the taste bud, could be identified (Fig. 6).

The taste bud in the rat consisted of the four cell types indicated in the Introduction. The Type I cell was dark in its cytoplasm and lacked a specific contact with nerves. The Type II cell was clear in its cytoplasm and characterized by a synapse-like association with nerves. Subsurface cisterns could occasionally be found along the synaptic membrane; no synaptic vesicles were recognized in this cell type.

The Type III cell was modest in cytoplasmic opacity and showed synaptic contacts with nerve terminal varicosities (Fig. 8). The synapses occurred at different heights of the cells, one and the same cell revealing two or more numerous synapses. So-called membrane condensations were visible as intermittent dark zones just beneath the synaptic membrane both on the cellular and nervous sides. The Type III cell was characterized by numerous synaptic vesicles which were partly gathered to the synaptic areas and partly dispersed in unspecific portions of the cytoplasm. Small clear vesicles (30 $\mathrm{nm}$ in diameter) were dominant, whereas a few large cored or peptidergictype granules $(50 \mathrm{~nm})$ were intermingled (Fig. 8). The synaptic vesicles of the former type were observed to line up close to the synaptic membrane, while those of the latter type tended to be located behind them, i.e., apart from the synaptic site. The Type III cell revealed, as did the Type I cell more numerously, several bundles of keratin-like filaments in the basal half of the cytoplasm. They mainly occurred near and basal to the nucleus, and the association of one of their ends with the plasma membrane could be observed.

Synaptic varicosities of nerves contained a moderate number of vesicles, mainly of the small clear type $(30 \mathrm{~nm})$ and partly of the large cored type $(50 \mathrm{~nm})$. Mitochondria were abundantly grouped in the nerves.

\section{DISCUSSION}

In their immunohistochemical study using the antibody against PGP 9.5, IwANAGA et al. (1992) demonstrated that spindle-shaped cells in rat taste bud, together with nerve fibers, were selectively immunostained, and so presumed that they were Type III or gustatory cells. This assumption was merely based on the knowledge that PGP 9.5 is a marker of certain paraneurons. The present study proves the validity of 
their assumption by electron-microscopic observation of the immunostained cells. We have also detected the occurrence of cells immunoreactive for this neuron-specific protein in the taste buds of the dog and identified them as gustatory cells (KANAZAWA, unpublished). Therefore, PGP 9.5 seems to be a useful marker for the identification of the Type III or gustatory cell.

The present study demonstrated at the electron microscope level that the PGP 9.5 immunoreactivity is located diffusely in the cytosol of the cell as it has been considered likely in the light microscope observations (IwANAGA et al., 1992 AstBÄck et al., 1995).

By a combination of electron microscopy and immunohistochemistry for PGP 9.5, the present study demonstrated a dense subgemmal nerve plexus issuing fine intragemmal fibers, with varicosities and knobs, up to different levels in the taste bud. These features of nerves have been known since early works using methylene blue staining and silver impregnation in various mammals (ARNSTEIN, 1893; KOLMER, 1927; etc.). By histochemistry for acetylcholinesterase, PARAN et al. (1975) confirmed this nervous arborization in the rat. More recent studies in the same species by Nishimoto et al. (1982) using immunohistochemistry for substance $P$ and by MüLLER (1996) using methylene blue staining rendered the earlier findings on the nerve supply of taste buds more precise and convincing.

Deserving special attention in the present study is the demonstration of a dense and delicate nerve plexus which was located in the basal portion within the taste bud, extending above the basal lamina. Few of the previous authors seem to have noticed this intragemmal structure. Some of the micrographs of the methylene blue stained rat taste bud in the paper by MülLER (1996, e.g., Figs. 2, 7, 9) show a dense basal plexus similar in appearance to ours, but it is unclear whether it is located above the basal lamina as our plexus is, nor does the author seem to have paid special attention to this plexus.

The occurrence of "nerve fibers ending within the taste pore" (MÜLLER, 1996) was described and drawn by ARNSTEIn (1893), BoteZAT (1902) and RETZIUS (1912) and carefully described and photographed in the methylene blue study by MüLleR (1996). The last author proposed "the possibility of paracellular pathways in taste transduction directly via the nerve fibers". The present study confirmed, under the light microscope, that darkly immunostained nerve fibers reach the taste pore. Our electron-microscopic observation could hardly demonstrate an immunostained fiber exposed to the taste pore. This problem, which is seriously related to the physiology of taste sensation, is expected to be settled morphologically in future studies.

The present electron-microscopic observations of the synapses and synaptic vesicles in the gustatory cells correspond to the findings by previous authors obtained in the rat (TAKEDA and Hoshino, 1975). The occurrence of synaptic vesicles both in the gustatory cell and in the nerve suggests a reciprocal nature of this synapsis, as previously noted in the gustatory cells of different animals (HIRATA, 1966; UCHIDA, 1980; YoshiE et al., 1990). It seems worthwhile to note that exocytotic images were induced in the rat (YosHIE et al., 1991c) and guinea pig (YOSHIE et al., 1991a, 1994) by exposing the lingual papillae concerned with tasting substances.

The present study confirms in the rat that the taste bud consists of the Type I (supportive cell), Type II (sensory cell of unknown nature), Type III (gustatory cell) and Type IV or basal cell, as has been reported in different mammals (e.g., in the rabbit: MURRAY et al., 1969; in the human: PARAN et al., 1975; in the rat: TAKEDA and HosHINO, 1975; in the mouse: TAKEDA, 1976; in the rhesus monkey: IDE and MUNGER, 1980 and FARBMAN et al., 1985; in the guinea pig: YoshIE et al., 1990).

To turn the discussion to the Type III or gustatory cell, this extends from the taste pore to the level of the basal lamina, as has been reported to be characteristic of the rat (TAKEDA and HosHINO, 1975) as well as of the dog (light-microscopically, RETzIUS, 1892, 1912; KANAZAWA, 1993) and cat (YoshIE et al., unpublished data); in the mouse and guinea pig, in contrast, it does not reach the bottom of the taste bud (YoshiE et al., 1990; SETA and Toyoshima, 1995). Taking into consideration that secretory granules/vesicles may open to the basal aspect of the Type III cell (in the dog, KanAZAWA, 1993), The different relation to the basal lamina of the Type III cell may possibly reflect different grades in the endocrine/paracrine activity of the cell.

The gustatory cells in the present study revealed conspicuous filament bundles which were believed to be keratin filaments. These structures were noticed by early histologists (KOLMER, 1927) and have been identified as certain type of keratin by modern histochemists (WONG et al., 1994).

The present study indicates that PGP 9.5 is a useful marker for investigating the cell characterization and innervation of the taste bud. Recent studies have revealed that PGP 9.5 is a ubiquitin carboxyl-terminal hydrolase (WILKINSON et al., 1989). It remains to be elucidated as to why certain neuronal and paraneuronal cells need to possess these specific moleculs of ubiquitins, which are contained in a wider spectrum variety of cells. 


\section{REFERENCES}

Arnstein, C.: Die Nervendigungen in den Schmeckbechern der Säuger. Arch. Mikrosk. Anat. 41: 195-218 (1893).

Astbäck, J., K. Arvidson and O. Johansson: Neurochemical markers of human fungiform papillae and taste buds. Regul. Pept. 59: 389-398 (1995).

Botezat, E.: Über das Verhalten der Nerven im Epithel der Säugethierzunge. Z. Wiss. Zool. 71: 211-226 (1902).

Delay, R. J., J. C. Kinnamon and S. D. Roper: Ultrastucture of mouse vallte taste buds: II. Cell types and cell lineage. J. Comp. Neurol. 253: 242-252 (1986).

Engström, H. and C. RYtzner: The fine structure of taste buds and taste finbers. Ann. Otol. Rhinol. Laryngol. 65: 361-365 (1956).

Farbman, A. I: Fine structure of the taste bud. J. Ultrastr. Res. 12: 328-350 (1965).

Farbman, A. I., G. Hellekant and A. Neison: Structure of taste buds in foliate papillae of the rhesus monkey, Macaca mulatta. Amer. J. Anat. 172: 41-56 (1985).

Fujimoto, S. and R. G. Murray : Fine structure of degeneration and regeneration in denervated rabbit vallate taste buds. Anat. Rec. 168: 393-414 (1970).

FuJiTA, T.: The gastro-enteric endocrine cell and its paraneuronic nature. In: (ed. by) R. E. Coupland and T. FujiTA: Chromaffin, enterochromaffin and related cells. Elsevier, Amsterdam, 1976 (p. 191-208).

Fujita, T., T. Kanno and S. Kobayashi: The paraneuron. Springer, Tokyo, 1988.

GraziadeI, P. P. C.: The ultrastructure of vertebrate taste buds. In: (ed. by) C. PfaffmAnN: Olfaction and taste. Rockefeller Univ. Press, New York, 1969 (p. 315330).

Hirata, Y.: Fine structure of the terminal buds on the barbels of some fishes. Arch. Histol. Jap. 26: 507-523 (1966).

IDÊ, C. and B. L. MungER: The cytologic composition of primate laryngeal chemosensory corpuscles. Amer. J. Anat. 158: 193-209 (1980).

Iwanaga, T., H. Takahashi-Iwanaga, T. Fujita, T. YAMAKUNI and Y. TAKAHASHI: Immunohistochemical demonstration of a cerebellar protein (spot 35 protein) in some sensory cells of guinea pigs. Biomed. Res. 6: 329-334 (1985).

IWANAGA, T., Y. TAKahashi and T. FUJiTa: Immunohistochemistry of neuron-specific and glia-specific proteins. Arch. Histol. Cytol. 52, Suppl.: 13-24 (1989).

Iwanaga. T., H. Han, H. Kanazawa and T. Fujita: Immunohistochemical localization of protein gene product 9.5 (PGP 9.5) in sensory paraneurons of the rat. Biomed. Res. 13: 225-230 (1992).

Kanazawa, H.: Fine structure of the canine taste bud with special reference to gustatory cell functions. Arch. Histol. Cytol. 56: 533-548 (1993).

Kinnamon, S. C. and T. A. Cummings: Chemosensory transduction mechanisms in taste. Annu. Rev. Physiol. 54: 715-731 (1992).
KolMER, W.: Geschmacksorgan. In: (ed. by) W. V. MöLLENDORFF: Handbuch der mikroskopischen Anatomie des Menschen, III/1. Springer, Berlin, 1927 (p. 154-191).

MüLleR, T.: The innervation of taste buds in the soft palate of the rat as revealed by methylene blue staining. Arch. Histol. Cytol. 59: 47-54 (1996).

MurRay, R. G.: Cell types in rabbit taste buds. In: (ed. by) C. Pfaffmann: Olfaction and taste. Rockefeller Univ. Press, New York, 1969 (p. 331-344).

- : Ultrastructure of taste receptors. In: (ed. by) L. M. BEIDLER: Handbook of sensory physiology, Vol. 4. Chemical senses, II. Taste. Springer, Berlin, 1971 (p. 3150).

Murray, R. G. and A. MurRay: Fine structure of taste buds of rabbit foliate papillae. J. Ultrastr. Res. 19: 327353 (1967).

-: Relations and possible significance of taste bud cells. In: (ed. by) W. D. NEEF: Contribution to sensory physiology, Vol. 5. Academic Press, New York, 1971 (p. 47-95).

Murray, R. G., A. Murray and S. Fujimoto: Fine structure of gustatory cells in rabbit taste buds. J. Ultrastr. Res. 27: 444-461 (1969).

Nishimoto, T., M. AKai, S. Inagaki, S. Shiosaka, Y. SimizU, K. Yamamoto, E. Senba, M. SakanaKa, K. Takatsuki, Y. Hara, H. Takagi, T. Matsuzaki, Y. KaWAI and M. Tohyama: On the distribution and origins of substance $\mathrm{P}$ in the papillae of the rat tongue: an experimental and immunohistochemical study. J. Comp. Neurol. 207: 85-92 (1982).

Paran. N., C. F. T. MatTern and R. I. Hankin: Ultrastructure of the taste bud of the human fungiform papilla. Cell Tiss. Res. 161: 1-10 (1975).

RETzius, G.: Die Nervenendigungen in dem Geschmacksorgan der Säugethiere und Amphibien. In: (ed. by) G. Retzius: Biologische Untersuchungen. IV. Samson \& Wallin, Stockholm, 1892 (p. 19-32).

- Zur Kenntnis der Geschmacksknospen beim Kaninchen. Biol. Untersuch. 17: 72-81 (1912).

ReutTeR, K. and M. WitT: Morphology of vertebrate taste organs and their nerve supply. In: (ed. by) S. A. SiMON and S. D. Roper: Mechanisms of taste transduction. CRC Press, Boca Raton, 1993 (p. 29-82).

Royer, S. M. and J. C. KInNamon: HVEM serial-section analysis of rabbit foliate taste buds: I. Type III cells and their synapses. J. Comp. Neurol. 306: 49-72 (1991).

- : Application of serial sectioning and three-dimensional reconstruction to the study of taste bud ultrastructure and organization. Microsc. Res. Tech. 29: 381-407 (1994).

Schwalbe, G.: Das Epithel der Papillae vallatae. Arch. Mikrosk. Anat. 3: 504-508. (1867).

SeTA, Y. and K. Toyoshima: Three-dimensional structure of the gustatory cell in the mouse fungiform taste buds: a computer-assisted reconstruction from serial ultrathin sections. Anat. Embryol. 191: 83-88 (1995).

TAKEDA, M.: An electron microscopic study on the innervation in the taste buds of the mouse circumvallate papillae. Arch. Histol. Jap. 39: 257-269 (1976). 
Takeda, M. and T. Hoshino: Fine structure of taste buds in the rat. Arch. Histol. Jap. 37: 395-413 (1975).

TaKEDA, M. and K. Kita0: Effect of monoamines on the taste buds in the mouse. Cell Tiss. Res. 210: 71-78 (1981).

Takeda, M., Y. Shishido, K. Kitao and Y. Suzuki: Biologenic monoamines in developing taste buds of mouse circumvallate papillae. Arch. Histol. Jap. 44: 485-495 (1981).

UCHIDA, T.: Ultrastructural and histochemical studies on the taste buds in some reptiles. Arch. Histol. Jap. 43: 459-478 (1980).

UGA, S.: A study on the cytoarchitecture of taste buds of rat circumvallate papillae. Arch. Histol. Jap. 31: 59-72 (1969).

Wilkinson, K. D., K. M. LeE, S. Deshapande, P. DuerksenHughes, J. M. Boss and J. PoHL: The neuron-specific protein PGP 9.5 is a ubiquitin carboxyl-terminal hydrolase. Science 246: 670-673 (1989).

Wong, L., B. O. OAKLey, A. Lawton and Y. Shiba: Keratin 19-like immunoreactivity in receptor cells of mammalian taste buds. Chem. Sens. 19: 251-264 (1994).

Yoshie, S., C. W AKasugi, Y. Teraki, T. Iwanaga and T. FUJITA: Immunocytochemical localizations of neuronspecific proteins in the taste buds of the guinea pig. Arch. Histol. Cytol. 51: 379-384 (1988).

Yoshie, S., Y. Teraki, T. Iwanaga and T. Fujita: Immunocytochemistry of neuron-specific proteins and neuropeptides in taste buds and associated nerves. Arch. Histol. Cytol. 52: 389-396 (1989).

Yoshie, S., C. Wakasugi, Y. Teraki and T. Fujita: Fine structure of the taste bud in guinea pigs. I. Cell characterization and innervation patterns. Arch. Histol. Cytol. 53: 103-119 (1990).
Yoshie, S., C. Wakasugi, Y. Teraki, H. Kanazawa, T. IwanaGa and T. Fujita: Response of the taste receptor cell to the umami-substance stimulus. An electronmicroscopic study. Physiol. Behav. 49: 887-889 (1991a).

Yoshie, S., C. Wakasugi, Y. Teraki, T. Iwanaga and T. Fusita: Fine structure of the taste bud in guinea pigs. II. Localization of Spot 35 protein, a cerebellar Purkinje cell-specific protein, as revealed by electorn-microscopic immunohistochemistry. Arch. Histol. Cytol. 54: 113-118 (1991b).

Yoshie, S., C. Wakasugi, Y. Teraki, H. Kanazawa and T. FUJiTa: Ultrastructural analysis of taste transduction. Proc. Symp. Taste Smell 25: 185-188 (1991c).

Yoshie, S., C. Wakasugi, H. Kanazawa and T. Fujita: Receptosecretory nature of the gustatory cell. In: (ed. by) K. Kurihara, N. Suzuki and H. Ogawa: Olfaction and taste, XI. Springer-Verlag, Tokyo, 1994 (p. 5-8).

Dr. Hiroaki KANAZAWA

Department of Anatomy

Niigata University School of Medicine Asahimachi, Niigata

951 Japan

金 澤 寛 明

951 新潟市旭町通 1

新潟大学医学部

第三解剖学教室 